\title{
PENERAPAN MODEL PEMBELAJARAN ROLE PLAYING UNTUK MENINGKATKAN KECERDASAN INTERPERSONAL SISWA KELAS IV SD INTEGRAL LUQMAN AL-HAKIM KABUPATEN SITUBONDO
}

\author{
Nur Holifatuz Zahro ${ }^{1)}$ \\ 1) Universitas Abdurachman Saleh Situbondo \\ holifatuzzahro@gmail.com
}

\begin{abstract}
ABSTRAK: Sekolah Dasar Integral Lukman Al-Hakim Kabupaten Situbondo menerapkan pendekatan penyelenggaraan dengan memadukan pendidikan umum dan pendidikan agama menjadi satu jalinan kurikulum. Sekolah ini juga menekankan keterpaduan dalam metode pembelajaran sehingga dapat mengoptimalkan ranah kognitif, afektif dan konotif. Implikasi dari keterpaduan ini menuntut pengembangan pendekatan proses pembelajaran yang kaya, variatif dan memerlukan media serta sumber belajar yang luas dan luwes. Salah satu model pembelajaran yang tepat guna untuk mengasah kecerdasan interpersonal siswa yaitu model role playing. Berdasarkan Penelitian yang dilakukan pada siklus Idan siklus II tersebut dapat diketahui bahwa kemampuan interpersonal anak mengalami peningkatan. Hal ini dibuktikan bahwa hasil penelitian pada prasiklus sebesar 27\%, siklus I sebesar 54,54\%, dan siklus II sebesar 81,81\%. Peningkatan ini terjadi karena adanya penyampaian meteri yang jelas dan pemberian dorongan yang kuat serta metode pembelajaran yang menarik dari guru. Hal ini disebabkan karena waktu yng digunakan guru untuk menyampaikan materi sudah efisien sehingga anak dapat bersosialisasi dan bekerja sama dalam memecahkan masalah secara bersama-sama.
\end{abstract}

Kata kunci : Kecerdasan Interpersonal, Role Playing

ABSTRACT: Situbondo District Integral Lukman Al-Hakim Primary School applies an implementation approach by combining general education and religious education into one interwoven curriculum. The school also emphasizes cohesiveness in learning methods so that it can optimize the cognitive, affective and connotive domains. The implications of this integration require the development of a learning process approach that is rich, varied and requires extensive and flexible media and learning resources. One of the appropriate learning models to hone students' interpersonal intelligence is the role playing model. Based on research conducted in the second cycle of Idan cycle it can be seen that the child's interpersonal abilities have increased. This is evidenced that the results of the prasiklus research by $27 \%$, the first cycle of $54.54 \%$, and the second cycle of $81.81 \%$. This increase occurred due to the delivery of clear material and the provision of strong encouragement and interesting learning methods from the teacher. This is because the time spent by the teacher to deliver the material is efficient so that children can socialize and work together in solving problems together.

Keywords: Interpersonal Intelligence, Role Playing

\section{PENDAHULUAN}

Kecerdasan bagaikan kumpulan kemampuan atau ketrampilan yang dapat ditumbuhkan dan dikembangkan. Kecerdasan adalah kemampuan untuk memecahkan 
suatu masalah, kemampuan untuk menciptakan masalah baru untuk dipecahkan, dan kemampuan untuk menciptakan sesuatuatau menawarkan suatu pelayanan yang berharga dalam suatu kebudayaan masyarakat. Tidak ada anak yang bodoh atau pintar, yang ada adalah anak yang menonjol dalam salah satu atau beberapa jenis kecerdasan (Widayati, 2008).

Kecerdasan Interpersonal adalah salah satu kecerdasan yang sangat penting dikembangkan pada usia dini. Kecerdasan Interpersonal menurut Harsanto (2005) adalah kemampuan untuk berealisasi atau berhubungan, serta memahami orang lain diluar dirinya. Pentingnya kecerdasan interpersonal adalah supaya anak dapat berbagi, berkomunikasi dan bergaul dengan orang lain terutama dengan teman sebaya.

Musfiroh (2008) menuliskan bahwa individu yang cerdas dalam interpersonal memiliki beberapa indikator kecerdasan interpersonal: 1) Sering didatangi orang lain untuk dimintai nasehat atu saran; 2) Lebih memilih kegiatan yang membutuhkan kerja tim; 3) Cenderung meminta tolong atau bicara dengan orang lain ketika menghadapi masalah dari pada menyelesaikan masalah sendiri; 4) Memiliki banyak teman; 5) Lebih menyukai permainan bersama untuk mengisi waktu; 6) menyukai tantangan untuk mengajar orang lain atau sekelompok orang tentang hal-hal yang disukai; 7)menganggap diri sendiri sebagai pemimpin; 8) Senang atau menikmati berada ditengah keramaian; 9) senang terlibat dalam kegiatan sosial.

Sekolah yang menjadi sasaran dalam penelitian ini adalah SD Integral Lukman Al-Hakim Kabupaten Situbondo. Dasar pertimbangan dilakukannya penelitian di SD Integral Lukman Al-Hakim adalah sekolah ini menerapkan pendekatan penyelenggaraan dengan memadukan pendidikan umum dan pendidikan agama menjadi satu jalinan kurikulum. Dengan pendekatan ini, semua mata pelajaran dan semua kegiatan sekolah tidak lepas dari bingkai ajaran dan pesan nilai Islam. Pelajaran umum, seperti matematika, IPA,IPS, bahasa, PKN, jasmani/kesehatan, dan seni dibingkai dengan pijakan, pedoman dan panduan Islam. Sementara dipelajaran agama, kurikulum diperkaya dengan pendekatan konteks kekinian dan kemanfaatan, dan kemaslahatan.

Berdasarkan hasil pengamatan awal di SD Integral Lukman Al-Hakim, peneliti mendapatkan informasi dari hasil observasi yang dilakukan dengan guru kelas IV, bahwa nilai muatan Bahasa Indonesia siswa khususnya pada keterampilan berbicara interpersonal tersebut masih terbilang belum maksimal. Hal ini terlihat berdasarkan nilai hasil belajar siswa yang dimiliki guru, bahwa dari 20 orang siswa kelas IV SD Integral Lukman Al-Hakim hanya 12 orang siswa (60\%) aja yang memperoleh nilai 75 keatas, selebihnya 6 orang siswa (30\%) memperoleh nilai 65-74, dan 2 orang (10\%) siswa yang lain yang memperoleh nilai antara 40-64. Hal ini menunjukkan siswa siswa kelas IV SD Integral Lukman Al-Hakim belum seluruhnya mencapai ketuntasan belajar, Siswa tersebut dapat dikatakan tuntas apabila memperoleh nilai 70 keatas sesuai dengan Kriteria Ketuntasan Minimal (KKM). 
Pada semester pertama masih banyak yang dibawah KKM (Kriteria Ketuntasan Minimal) sekolah, yaitu 70 dengan model pembelajaran yang digunakan yang biasa diterapkan. Kondisi di kelas cenderung lebih ramai dalam proses kegiatan belajar mengajar, sehingga siswa kurang memperhatikan penjelasan dari guru. Akibatnya, pemahaman darisuatu materi yang telah disampaikan guru tidak dapat diterima dan dipahamidengan baik oleh siswa tersebut. Dari permasalahan tersebut, peneliti mencoba untuk memberikan suatu cara agar proses pembelajaran di dalam kelas bisa lebih efektif.

Salah satu model pembelajaran yang tepat guna untuk mengasah kecerdasan interpersonal siswa yaitu model role playing (bermain peran). Heldebrand, dalam Moeslichatoen (2004:9) berpendapat bahwa untuk mengembangkan kognisi anak dapat dipergunakan metode-metode yang mampu menggerakan anak agar menumbuhkan berfikir, menalar, maupun menarik kesimpulan, dan membuat generalisasi. Caranya adalah dengan memahami lingkungan di sekitarnya, mengenal orang-orang dan benda-benda yang ada, memahami tubuh dan perasaan mereka sendiri, melatih memahami untuk mengurus diri sendiri. Selain itu melatih anak menggunakan bahasa untuk berhubungan dengan orang lain, dan melakukan apa yang dianggap benar berdasarkan nilai-nilai yang berlaku dalam masyarakat.

Hasil penelitian dari Hartup (dalam Safaria, 2005) menegaskan bahwa anak dengan hubungan sebaya yang buruk memiliki peluang yang lebih besar untuk mengalami gangguan neurotik dan psikotik, gangguan tingkah laku, kenakalan, gangguan dalam perilaku seksual, serta penyesuaian diri di masa dewasa. Sebaliknya anak dengan hubungan sebaya yang positif lebih matang dan mampu menyesuaikan diri di masa dewasanya. Hasil penelitian tersebut menegaskan bahwa pentingnya kemampuan komunikasi interpersonal bagi anak.

Anak membutuhkan kemampuan interpersonal yang tinggi agar mampu dan terampil bergaul dengan sebayanya. Kecerdasan interpersonal ini tidak dibawa anak sejak lahir, namun diperoleh melalui proses belajar yang berkesinambungan. Anak membutuhkan pelatihan dan bimbingan untuk dapat meningkatkan kemampuan komunikasi interpersonalnya.

Hal yang menjadi titik berat di sini, bahwa berdasarkan kajian literatur terdapat banyak teknik yang dapat digunakan untuk membantu siswa dalam meningkatkan keterampilan interpersonal, salah satunya adalah teknik Role Playing. Para ahli psikologi behavior menggunakan teknik tersebut untuk melatih ahli komunikasi atau ahli hubungan interpersonal dalam lingkungan.

Jackson (2011) menemukan role play sangat membantu peserta didik yang sulit terlibat aktif berkomunikasi dalam proses pembelajaran disekolah dengan cara yang tidak menimbulkan kecemasan. Selain itu role play juga memberikan manfaat kepada pendidik dalam hal bagaimana dan kapan sebaiknya memberikan umpan balik dalam proses pembelajaran agar terdengar menyenangkan untuk peserta didik. 
Selain itu, Najlatun \& Galih (2013) dalam penelitiannya menemukan bahwa role palying dapat secara efektif meningkatkan kemampuan komunikasi interpersonal siswa.

Bermain, khususnya permainan peran, adalah aktivitas yang menyenangkan bagi siswa, dan keterampilan komunikasi interpersonal dapat diperoleh melalui proses belajar, karena tingkah laku tersebut merupakan hasil dari belajar. Karena alasan tersebut dilakukan penelitian tentang Penerapan Model Pembelajaran Role Playing untuk Meningkatkan Kecerdasan Interpersonal Siswa Kelas IV SD Integral Lukman AlHakim Kabupaten Situbondo Tahun Ajaran 2018/2019.

\section{Identifikasi Masalah}

Sebagaimana telah dikemukakan dalam latar belakang masalah serta dari pengamatan awal ditemukan beberapa fenomena yang dipilih sebagai objek perhatian untuk dikaji secara ilmiah. Masalah tersebut dapat diidentifikasikan sebagai berikut:

1. Kurangnya interaksi antara guru dengan siswa selama kegiatan belajar mengajar di kelas

2. Metode pembelajaran yang digunakan oleh guru selama kegiatan belajar mengajar di kelas kurang menarik.

3. Nilai muatan Bahasa Indonesia siswa khususnya pada keterampilan berbicara interpersonal masih belum maksimal

\section{Rumusan Masalah}

Berdasarkan latar belakang tersebut di atas, maka rumusan masalah yang akan menjadi fokus adalah : "Bagaimanakah penerapan model pembelajaran role playing untuk meningkatkan kecerdasan interpersonal siswa kelas IV SD Integral Lukman AlHakim Kabupaten Situbondo tahun ajaran 2018/2019?”

\section{Tujuan Penelitian}

Tujuan penelitian ini adalah : Untuk mengetahui penerapan model pembelajaran role playing dapat meningkatkan kecerdasan interpersonal siswa kelas IV SD Integral Lukman Al-Hakim Kabupaten Situbondo tahun ajaran 2018/2019

\section{Hipotesis}

Berdasarkan uraian latar belakang dan identifikasi di atas, dapat dirumuskan hipotesis sebagai berikut: Dengan menerapan model pembelajaran Role Playing dapat meningkatkan kecerdasan interpersonal siswa Kelas IV SD Integral Lukman Al-Hakim Kabupaten Situbondo tahun ajaran 2018/2019. 


\section{Kajian Kecerdasan Interpersonal}

Interpersonal merupakan suatu hubungan antar individu dengan orang lain. Hubungan interpersonal yang efektif seperti persahabatan, jika mereka memiliki kemampuan-kemampuan dalam membina hubungan interpersonal. Kemampuan tersebut secara khusus oleh Buhrmester dkk (1988) disebut sebagai interpersonal competence. Menurut Buhrmester, Firman, Witenberg dan Reis (1988) mengatakan bahwa interpersonal competence adalah keterampilan atau kemampuan yang dimiliki individu untuk membina hubungan yang baik dan efektif dengan orang lain atau antar individu.

Kecerdasan Interpersonal adalah salah satu kecerdasan yang sangat penting dikembangkan pada usia dini. Kecerdasan Interpersonal menurut Harsanto (2005:7) adalah kemampuan untuk berealisasi atau berhubungan, serta memahami orang lain diluar dirinya. Pentingnya kecerdasan interpersonal adalah supaya anak dapat berbagi, berkomunikasi dan bergaul dengan orang lain terutama dengan teman sebaya.

Musfiroh (2008) menuliskan bahwa individu yang cerdas dalam interpersonal memiliki beberapa indikator kecerdasan interpersonal: 1) Sering didatangi orang lain untuk dimintai nasehat atu saran; 2) Lebih memilih kegiatan yang membutuhkan kerja tim; 3) Cenderung meminta tolong atau bicara dengan orang lain ketika menghadapi masalah dari pada menyelesaikan masalah sendiri; 4) Memiliki banyak teman; 5) Lebih menyukai permainan bersama untuk mengisi waktu; 6) menyukai tantangan untuk mengajar orang lain atau sekelompok orang tentang hal-hal yang disukai; 7)menganggap diri sendiri sebagai pemimpin; 8) Senang atau menikmati berada ditengah keramaian; 9) senang terlibat dalam kegiatan sosial.

Dari beberapa pengertian yang dipaparkan di atas, dapat dimaknai kecerdasan interpersonal merupakan kemampuan untuk melakukan komunikasi secara lebih efektif yang meliputi kemampuan untuk memulai suatu hubungan antar individu dengan yang lain secara interpersonal, kemampuan membuka diri, kemampuan untuk memberikan bersikap asertif, kemampuan untuk memberikan dukungan emosional kepada orang lain, empati serta kemampuan mengelola dan mengatasi konflik dengan orang lain.

\section{Aspek- Aspek dalam Kecerdasan Interpersonal}

Buhrmester, dkk (1988) menyatakan interpersonal competence meliputi aspekaspek sebagai berikut:

a. Kemampuan berinisiatif Menurut Buhrmester (1988) inisiatif adalah usaha untuk memulai suatu bentuk interaksi dan hubungan dengan orang lain, atau dengan lingkungan sosial yang lebih besar. Inisiatif merupakan usaha pencarian pengalaman baru yang lebih banyak dan luas tentang dunia luar, juga tentang dirinya sendiri dengan tujuan untuk mencocokkan sesuatu atau informasi yang telah diketahui agar dapat lebih memahaminya. 
b. Kemampuan untuk bersikap terbuka (self-disclosure) Kemampuan membuka diri merupakan kemampuan untuk membuka diri, menyampaikan informasi yang bersifat pribadi dan penghargaan terhadap orang lain. Kartono dan Gulo (1987) mengungkap bahwa pembukaan diri adalah suatu proses yang dilakukan seseorang hingga dirinya dikenal oleh orang lain. Sears,dkk, (1991) menyatakan bahwa kemampuan membuka diri diwujudkan dengan perilaku orang yang melakukan kegiatan membagi perasaan dan informasi yang akrab dengan orang lain.

c. Kemampuan bersikap asertif Menurut Pearlman dan Cozby (1983) asertivitas adalah kemampuan dan kesediaan individu untuk mengungkapkan perasaanperasaan secara jelas dan dapat mempertahankan hak-haknya dengan tegas. Dalam konteks komunikasi interpersonal seringkali seseorang harus mampu mengungkapkan ketidaksetujuannya atas berbagai macam hal atau peristiwa yang tidak sesuai dengan alam pikirannya.

d. Kemampuan memberikan dukungan emosional Kemampuan memberikan dukungan emosional sangat berguna untuk mengoptimalkan komunikasi interpersonal antar dua pribadi. Beker dan Lemie (dalam Buhrmester, dkk, 1988) dukungan emosional mencakup kemampuan untuk menenangkan dan memberi rasa nyaman kepada orang lain ketika orang tersebut dalam keadaan tertekan dan bermasalah. Kemampuan ini lahir dari adanya empati dalam diri seseorang.Kemampuan dalam mengatasi konflik Kemampuan mengataasi konflik meliputi sikap-sikap untuk menyusun strategi penyelesaian masalah, mempertimbangkan kembali penilaian atau suatu masalah dan mengembangkan konsep harga diri yang baru. Menyusun strategi penyelesaian masalah adalah bagaimana individu yang bersangkutan merumuskan cara untuk menyelesaikan konflik dengan sebaik-baiknya.

\section{Model Pembelajaran Role Playing}

Melihat manfaat besar bermain untuk kehidupan anak-anak, dapat dilakukan inovasi menggunakan bermain sebagai model pembelajaran. Karena bermain dapat membantu siswa memahami materi pelajaran lebih mendalam dengan melakukan permainan tentang materi pelajaran yang disajikan. Inovasi pembelajaran yang sudah dilakukan dikenal dengan model pembelajaran bermain peran atau role playing. Pernyataan ini didukung oleh Santoso (2011) yang mengatakan bahwa model role playing adalah suatu cara penguasaan bahan-bahan pelajaran melalui pengembangan imajinasi dan penghayatan siswa yang di dalamnya terdapat aturan, tujuan, dan unsur senang dalam melakukan proses belajar mengajar. Jill Hadfield dalam Santoso (2011) menguatkan bahwa role playing adalah sejenis permainan gerak yang didalamnya ada tujuan, aturan dan sekaligus melibatkan unsur senang. Wikipedia (2012) juga mengemukakan bahwa role playing adalah sebuah permainan yang para pemainnya 
memainkan peran tokoh-tokoh khayalan dan berkolaborasi untuk merajut sebuah cerita bersama. Hal ini diperkuat pendapat Hadari Nawawi dalam Kartini (2007) yang menyatakan bahwa bermain peran (role playing) adalah mendramatisasikan cara bertingkah laku orang-orang tertentu dalam posisi yang membedakan peranan masingmasing dalam suatu organisasi atau kelompok di masyarakat.

\section{Langkah-langkah Model Pembelajaran Role Playing}

Setiap model pembelajaran aktif, ada beberapa langkah-langkah yang harus dilakukan. Berikut langkah-langkah penerapan model role playing menurut Mulyadi (2011) :

1. Guru menyiapkan skenario yang akan ditampilkan.

2. Menunjuk beberapa siswa untuk mempelajari skenario dalam waktu beberapa hari sebelum Kegiatan Belajar Mengajar.

3. Guru membentuk kelompok yang anggotanya lima orang (menyesuaikan jumlah siswa)

4. Memberikan penjelasan tentang kompetensi yang ingin dicapai.

5. Memanggil para siswa yang sudah ditunjuk untuk melakonkan skenario yang sudah dipersiapkan.

6. Masing-masing siswa berada di kelompoknya sambil mengamati skenario yang sedang diperagakan.

7. Setelah selesai ditampilkan, masing-masing siswa diberi lembar kerja untuk membahas penampilan yang selesai diperagakan.

8. Masing-masing kelompok menyampaikan hasil kesimpulannya.

9. Guru memberi kesimpulan secara umum.

10. Evaluasi

11. Penutup

\section{METODE PENELITIAN}

Jenis penelitian ini adalah Penelitian Tindakan Kelas (Classroom Action Reseach. Menurut Elliot (dalam Kartono et al, 2013) mendefinisikan bahwapenelitian tindakan sebagai kajian tentang situasi sosial dengan tujuan untukmeningkatkan kualitas tindakan didalamnya. Berdasarkan pengertian tersebutdapat dinyatakan bahwa penelitian tindakan kelas adalah suatu kajian yang terencana dan sistematis yang dilakukan oleh peneliti untuk proses perbaikan pembelajaran di kelas.

\section{Tempat}

Penelitian Tindakan Kelas (PTK) ini dilaksanakan di kelas IV SD Integral Luqman Al Hakim Sumberkolak Kecamatan Panarukan Kabupaten Situbondo semester 
2 muatan mata pelajaran Bahasa Indonesia keterampilan berbicara pada topik kemampuan interpersonal. Pemilihan sekolah ini bertujuan untuk membekali dan meningkatkan kecerdasan interpersonal siswa di sekolah tersebut.

\section{Waktu Penelitian}

Penelitian Tindakan Kelas (PTK) ini akan dilaksanakan pada bulan Maret sampai dengan Mei 2019. Penentuan waktu penelitian mengacu padakalender akademik sekolah, karena PTK memerlukan beberapa siklus yang membutuhkan proses tindakan pembelajaran yang efektif di kelas. Penelitian ini dilaksanakan melalui dua siklus untuk melihat progres peningkatan kecerdasan interpersonal siswa melalui penerapan model pembelajaran role playing.

\section{Tabel 1. Jadwal Kegiatan Penelitian}

\begin{tabular}{|c|l|c|c|c|}
\hline \multirow{2}{*}{ No } & \multicolumn{1}{|c|}{ Jenis Kegiatan } & \multicolumn{2}{c|}{ Bulan } \\
\cline { 5 - 5 } & & Maret & April & Mei \\
\hline 1. & Merumuskan dan Pemantapan Judul & & & \\
\hline 2. & Pemantapan Proposal Penelitian & & \\
\hline 3. & Seleksi Proposal Penelitian & & \\
\hline 4. & Pelaksanaan Tindakan Penelitian & & \\
\hline 5. & Menganalisis Data & & \\
\hline 6. & Membuat Laporan Akhir Penelitian & & & \\
\hline 7. & Menyelesaikan Administrasi & & & \\
\hline
\end{tabular}

\section{Subyek Penelitian}

Subyek dalam Penelitian Tindakan Kelas (PTK) ini adalah siswa kelas IV SD Integral Luqman Al Hakim tahun pelajaran 2018/2019 dengan jumlah siswa sebanyak 20 orang. Menurut Iskandar (2012) menyatakan bahwa model Penelitian Tindakan Kelas (PTK) berbentuk spiral dengan masing-masing siklus terdiri dari empat tahap, yaitu perencanaan, tindakan,pengamatan,dan refleksi. Siklus penelitian dapat direncanakan dua siklus atau lebih sesuaidengan tercapainya kriteria keberhasilan yang direncanakan. Apabila dua siklusatau lebih dan kriteria keberhasilan belum tercapai maka peneliti dapatmempertimbangkan untuk menghentikan siklusnya.

Pada dasarnya tidak ada batasan sampai berapa siklus harus dilakukan, namun demikian rasa kepuasan peneliti juga merupakan pertimbangan untuk menetapkan banyaknya siklus yang dilakukan. Berdasarkan hal tersebut maka kriteria 
keberhasilan harus ditetapkan sesuai dengan kemampuan. Adapun langkah-langkah Penelitian Tindakan Kelas (PTK), seperti yang digambarkan di bawah ini.

\section{Tindakan Penelitian}

Dalam Tindakan Penelitian Tindakan Kelas (PTK) ini menggunakan beberapa tahapan yang meliputi: tahap perencanaan, pelaksanaan tindakan, pengamatan, dan refleksi. Penelitian ini dilaksanakan sebanyak dua siklus, siklus 1 sebagai wujud perbaikan tetapi jika masih ada yang belum tuntas dilakukan siklus 2 sebagai penguatan dari perbaikan kedua.Sedangkan yang diteliti adalah pencapaian peningkatan kecerdasan interpersonal siswa melalui penerapan model pembelajaran role playing. Tahapan pelaksanaan siklus dalam penelitian ini sebagai berikut:

\section{a. Pra Siklus}

Tahap pra siklus dilakukan untuk mengidentifikasi masalah yang terjadi didalam kelas yang mempengaruhi tingkat hasil belajar siswa. Tahap pra siklus meliputi :

1) Tahap Perencanaan (Planning)

Menyiapkan bahan-bahan yang diperlukan dalam pelaksanaan penelitian, meliputi:

a. Menyiapkan rencana pembelajaran (RPP)

b. Mengecek keseuaian model pembelajaran yang dirumuskan.

\section{2) Tahap Pelaksanaan Kegiatan}

Pelaksanaan tindakan ini merupakan pelaksanaan kegiatan pembelajaran yang telah disiapkan sebelumnya. Pelaksanaan tindakan ini meliputi kegiatan sebagai berikut:

a. Guru menyajikan materi Bahasa Indonesia dengan muatan keterampilan berbicara

b. Guru bertanya jawab dengan siswa mengenai hal yang belum diketahui siswa.

c. Guru memberikan kesimpulan materi yang disajikan.

3) Tahap Pengamatan (Observasi)

Pada kegiatan observasi peneliti mengobservasi kegiatan belajar mengajar meliputi aktivitas belajar siswa, aktivitas mengajar guru hingga proses evaluasi pembelajaran

4) Tahap Refleksi

Kegiatan pada tahap refleksi adalah mengkaji hal yang telah terjadi selama pelaksanaan tindakan dan observasi berlangsung. Pengkajian kembali digunakan 
untuk mengetahui jika permasalahan yang terjadi pada saat pelaksanaan tindakan observasi. sehingga pelu dilakukan kegiatan pembelajaran selanjutnyadi Siklus I

\section{b. Siklus 1}

Sesuai dengan kaidah penulisan PTK, maka tahapan pelaksanaan PTK siklus 1 ini dimulai dari tahap perencanaan, tindakan, pengamatan, dan refleksi seperti yang tertulis dibawah ini:

1) Tahap Perencanaan tindakan

Kegiatan yang akan dilaksanakan dalam tahap perencanaan tindakanmeliputi:

a) Melakukan analisis kurikulum untuk mengetahui kompetensi dasar yang akan disampaikan kepada siswa dalam pembelajaran;

b) Membuat rencana pembelajaran dengan mengacu pada tindakan yang diterapkan dalam PTK siklus 1 dengan penerapan model pembelajaran Role Playing, meliputi:

c) Menyiapkan teks petunjuk kerja

d) Menyiapkan naskah/skenario bermain peran;

e) Menyusun alat evaluasi pengukuran tingkat kemampuan interpersonal.

2) Tahap Pelaksanaan Tindakan

Kegiatan yang akan dilaksanakan dalam tahap pelaksanaan tindakan meliputi:

a) Guru menyiapkan skenario yang akan ditampilkan.

b) Menunjuk beberapa siswa untuk mempelajari skenario dalam waktu beberapa hari sebelum Kegiatan Belajar Mengajar.

c) Guru membentuk kelompok yang anggotanya lima orang (menyesuaikan jumlah siswa)

d) Memberikan penjelasan tentang kompetensi yang ingin dicapai.

e) Memanggil para siswa yang sudah ditunjuk untuk melakonkan skenario yang

f) sudah dipersiapkan.

g) Masing-masing siswa berada di kelompoknya sambil mengamati skenario

h) yang sedang diperagakan.

i) Setelah selesai ditampilkan, masing-masing siswa diberi lembar kerja untuk membahas penampilan yang selesai diperagakan.

j) Masing-masing kelompok menyampaikan hasil kesimpulannya.

k) Guru memberi kesimpulan secara umum.

1) Evaluasi

m) Penutup

3) Tahap Pengamatan Tindakan

Kegiatan yang akan dilaksanakan dalam tahap pengamatan tindakan meliputi:

a) Guru mengamati situasi kegiatan belajar mengajar; 
b) Guru mengamati aktivitas siswa dalam pembelajaran;

c) Guru mengamati peningkatan kecerdasan interpersonal siswa

4) Tahap Refleksi Terhadap Tindakan

Kegiatan yang akan dilaksanakan dalam tahap refleksi tindakan meliputi:

a) Guru menganalisis dan menyimpulkan hasil pembelajaran;

b) Guru mencatat kekurangan dalam proses pembelajaran siklus 1 untuk diperbaiki di siklus berikutnya;

c) Guru mencatat kelebihan dalam proses pembelajaran siklus 1 untuk ditingkatkan di siklus-siklus berikutnya (apabila diperlukan)

\section{c. Siklus 2}

1) Tahap Perencanaan tindakan

Kegiatan yang akan dilaksanakan dalam tahap perencanaan tindakanmeliputi:

a) Melakukan analisis RPP dan pembelajaran siklus 2 untuk mengetahui kompetensi dasar yang akan disampaikan kepada siswa dalam pembelajaran;

b) Membuat rencana pembelajaran dengan mengacu pada tindakan yang diterapkan dalam PTK siklus 2 masih dengan penerapan model pembelajaran Role Playing, meliputi:

c) Menyiapkan teks petunjuk kerja

d) Menyiapkan naskah/skenario bermain peran;

e) Menyusun alat evaluasi pengukuran tingkat kemampuan interpersonal.

2) Tahap Pelaksanaan Tindakan

Kegiatan yang akan dilaksanakan dalam tahap pelaksanaan tindakan meliputi:

a) Guru menyiapkan skenario yang akan ditampilkan.

b) Menunjuk beberapa siswa untuk mempelajari skenario dalam waktu beberapa hari sebelum Kegiatan Belajar Mengajar.

c) Guru membentuk kelompok yang anggotanya lima orang (menyesuaikan jumlah siswa)

d) Memberikan penjelasan tentang kompetensi yang ingin dicapai.

e) Memanggil para siswa yang sudah ditunjuk untuk melakonkan skenario yang sudah dipersiapkan.

f) Masing-masing siswa berada di kelompoknya sambil mengamati skenario yang sedang diperagakan. 
g) Setelah selesai ditampilkan, masing-masing siswa diberi lembar kerja untuk membahas penampilan yang selesai diperagakan.

h) Masing-masing kelompok menyampaikan hasil kesimpulannya.

i) Guru memberi kesimpulan secara umum.

j) Evaluasi

k) Penutup

3) Tahap Pengamatan Tindakan

Kegiatan yang akan dilaksanakan dalam tahap pengamatan tindakan meliputi:

a) Guru mengamati situasi kegiatan belajar mengajar;

b) Guru mengamati aktivitas siswa dalam pembelajaran;

c) Guru mengamati peningkatan kecerdasan interpersonal siswa

4) Tahap Refleksi Terhadap Tindakan

Kegiatan yang akan dilaksanakan dalam tahap refleksi tindakan meliputi:

a) Guru menganalisis dan menyimpulkan hasil pembelajaran;

b) Guru mencatat kekurangan dalam proses pembelajaran siklus 1 untuk diperbaiki di siklus berikutnya;

c) Guru mencatat kelebihan dan hasil dalam proses pembelajaran siklus 2 untuk ditingkatkan di siklus-siklus berikutnya.

Penelitian ini dianalisis secara deskriftif kualitatif yang terdiri dari reduksi pemaparan data dan penyimpulan hasil analisis. Pengumpulan data dilakukan dalam suatu proses siklus, membandingkan siklus satu dan siklus dua. Reduksi data adalah pemilihan, pemusatan, penyederhanaan data besar yang muncul pada hasil catatan lapangan. Analisis data pada penelitian ini meliputi:

1. Menunjukkan skor yang dapat dicapai pada setiap butir amatan.

2. Membuat tabulasi skor observasi pengembangan kemampuan interpersonal anak yang terdiri dari nomor, nama anak, butir amatan, jumlah skor dan hasil prosentase.

3. Proses pengembangan kemampuan interpersonal anak melalui metode proyek dengan cara sebagai berikut:

Jumlah skor butir yang dicapai setiap anak x 100\%

Jumlah skor maksimum

4. Skor maksimum $=$ skor butir amatan $\mathrm{x}$ jmlah butir amatan

5. Hasil prosentase diisikan pada tabel tabulasi kolom(\%) 
Instrumen adalah alat bantu yang digunakan untuk mengumpulkan data penelitian (sanjaya, 2011). Pembuatan instrumen pada penelitian ini sebagai berikut:

1. Lembar observasi perkembangan kemampuan interpersonal anak

2. Lembar observasi yang digunakan untuk hasil pengamatan saat

3. melaksanakan kegiatan.

4. Lembar observasi kinerja guru dalam proses kegiatan pembelajaran

5. menggunakan metode proyek.

Indikator pencapaian, keberhasilan ini dapat dilihat dengan adanya perubahan terhadap perkembangan kemampuan interpersonal anak meliputi memiliki kemampuan untuk memahami orang lain dan berkomunikasi efektif baik ecara verbal maupun non verbal, berempati besar terhadap perasaan orang lain, menikmati permainan kelompok, mampu menyesuaikan dengan lingkungan dan kelompok yang berbeda. Penelitian ini dikatakan berhasil apabila $75 \%$ dari jumlah anak dapat mencapai target keberhasilan.

Berdasarkan Penelitian yang dilakukan pada siklus Idan siklus II tersebut dapat diketahui bahwa kemampuan interpersonal anak mengalami peningkatan. Hal ini dibuktikan bahwa hasil penelitian pada prasiklus sebesar $27 \%$, siklus I sebesar $54,54 \%$, dan siklus II sebesar $81,81 \%$. Peningkatan ini terjadi karena adanya penyampaian meteri yang jelas dan pemberian dorongan yang kuat serta metode pembelajaran yang menarik dari guru. Hal ini disebabkan karena waktu yng digunakan guru untuk menyampaikan materi sudah efisien sehingga anak dapat bersosialisasi dan bekerja sama dalam memecahkan masalah secara bersama-sama.

\section{KESIMPULAN}

Penerapan me Dengan menerapan model pembelajaran Role Playing dapat meningkatkan kecerdasan interpersonal siswa Kelas IV SD Integral Lukman Al-Hakim Kabupaten Situbondo tahun ajaran 2018/2019 yaitu dari dari 27\% (pra-siklus) menjadi $54,54 \%$, (siklus (1) dan menjadi semakin meningkat $81,81 \%$ (siklus 2)

\section{DAFTAR RUJUKAN}

Hasanto Radno. 2005. Melatih Anak Berfikir Analisis, Kritis dan Kreatif. Semarang: PT Gramedia Widiasana Indonesia.

Mositoh ,dkk. 2006. Strategi Pembelajaran Taman Kanak-kanak. Jakarta: Universitas Terbuka.

Mulyasa, H.E. 2009. Praktek Penelitian Tindakan Kelas. Bandung: Rodakarya. 
Romlah T. 2006. Teori dan Praktik Bimbingan Kelompok. Malang: Universitas Negeri Malang.

Najlatun, N. \& Galih, W. 2013. Penerapan Teknik Bermain Peran dalam Bimbingan Kelompok untuk Mening-katkan Kemampuan Komunikasi Inter-personal siswa kelas $\mathrm{X}$ Multimedia SMK IKIP Surabaya. Journal Mahasiswa Bimbingan Konseling, 1 (1): 61-78.

Romlah T. 2006. Teori dan Praktik Bimbingan Kelompok. Malang: Universitas Negeri Malang. 